Winter 2012

\title{
Department of Defense, Inc.: The DoD's Use of Corporate Strategies to Manage U. S. Overseas Military Bases
}

\author{
Matt Weyand \\ Indiana University Maurer School of Law, aweyand@indiana.edu
}

Follow this and additional works at: https://www.repository.law.indiana.edu/ijgls

Part of the Business Organizations Law Commons, Government Contracts Commons, and the Military, War, and Peace Commons

\section{Recommended Citation}

Weyand, Matt (2012) "Department of Defense, Inc.: The DoD's Use of Corporate Strategies to Manage U. S. Overseas Military Bases," Indiana Journal of Global Legal Studies: Vol. 19 : Iss. 1 , Article 15. Available at: https://www.repository.law.indiana.edu/ijgls/vol19/iss1/15

This Note is brought to you for free and open access by the Law School Journals at Digital Repository @ Maurer Law. It has been accepted for inclusion in Indiana Journal of Global Legal Studies by an authorized editor of Digital Repository @ Maurer Law. For more information, please contact rvaughan@indiana.edu.

\section{$\Psi$}

JEROME HALL LAW LIBRARY

INDIANA UNIVERSITY

Maurer School of Law
Blooming ton 


\title{
Department of Defense, Inc.: The DoD's Use of Corporate Strategies to Manage U.S. Overseas Military Bases
}

\author{
MATT WEYAND*
}

\begin{abstract}
This paper examines the Department of Defense's use of corporate strategies to manage U.S. overseas military bases and concludes that the Department of Defense's continued use of these corporate strategieswhich have negatively impacted the United States' relationship with host nations-depends on the Department of Defense's ability to successfully strike a balance between efficiency and diplomacy.
\end{abstract}

\section{INTRODUCTION}

The Department of Defense (DoD) operates and maintains nearly 1,000 overseas military bases. ${ }^{1}$ Overseas military bases serve many strategic functions ${ }^{2}$ that contribute to one overarching purpose: to provide security for U.S. citizens. The United States faced new security threats, ${ }^{3}$ unlike those after World War II (WWII), when it laid the

* Executive Online Editor, Indiana Journal of Global Legal Studies; J.D. Candidate, 2012, Indiana University Maurer School of Law; B.A. magna cum laude, 2005, Santa Clara University. I would like to thank Professor Alfred C. Aman for his guidance and advice. I would also like to thank Allison Walker for her support and for proofreading the initial drafts of this paper. Finally; I would like to thank my grandfathers, Lieutenant General Alexander M. Weyand (Ret.) and Major General Eugene S. Korpal (Ret.), for their service and for inspiring my general interest in military history and strategy.

1. Chalmers Johnson, Dismantling the Empire: America's Last Best Hope 111 (2010) [hereinafter JOHNSON, EMPIRE].

2. For example, overseas military bases encircle enemies, reinforce the status quo, serve as training centers for U.S. troops, and influence host nations. See Joseph Gerson, U.S. Foreign Military Bases and Military Colonialism: Personal and Analytical Perspectives, in The Bases OF EMPIRE: The Global Struggle Against U.S. MilitaRY PoSTS 47, 54-56 (Catherine Lutz ed., 2009).

3. See Exec. Office of the President, National SeCurity Strategy 17 (2010) [hereinafter NATIONAL SECURITY STRATEGY].

Indiana Journal of Global Legal Studies Vol. $19 \# 1$ (Winter 2012)

(C) Indiana University Maurer School of Law 
foundations of its current basing infrastructure. ${ }^{4}$ In his 2010 National Security Strategy, President Obama described these new threats to American security: "Instead of a hostile expansionist empire, we now face a diverse array of challenges, from a loose network of violent extremists to states that flout international norms or face internal collapse . . . the United States must now be prepared for asymmetric threats." 5 The nature of national security has changed, and the American security state ${ }^{6}$ has adapted in response.

The DoD, the United States' oldest government agency, ${ }^{7}$ is the organizational embodiment of the American security state. Since the early 2000 s, the DoD has transformed the U.S. military to better operate in the new global security environment. ${ }^{8}$ As part of this transformation, the DoD has reconfigured its overseas-basing posture. ${ }^{9}$

The American security state, as embodied by the DoD, has dramatically changed its modus operandi in response to new security risks. To economically and efficiently "manufacture" the "product" known as security, the DoD has increasingly operated like a transnational corporation: it has adopted the corporate strategies of rightsizing, ${ }^{10}$ outsourcing, and offshoring. ${ }^{11}$ By rightsizing, outsourcing, and offshoring, the DoD has accrued many of the same benefits as a transnational corporation: it has been able to operate more efficiently, more effectively, and more economically. But the DoD is not a transnational corporation, and operating as such risks the breakdown of cooperation, alliances, and diplomacy between the United States and nations hosting U.S. bases.

4. See Catherine Lutz, Introduction: Bases, Empire, and Global Response to THE Bases of EmpIre: The Global Struggle Against U.S. Military Posts 1, 12 (Catherine Lutz ed., 2009).

5. NATIONAL SECURITY STRATEGY, supra note 3, at 17.

6. The American security state provides national security for U.S. citizens. National security "refers to organized political violence." See Jonathan Kirshner, Globalization and National Security, in GLOBALIZATION AND NATIONAL SECURITY 1, 2 (Jonathan Kirshner ed., 2006). For a more detailed description of the security state, see Ian Clark, The Security State, in The Global Transformations READER: AN INTRODUCTION TO THE GLobalization Debate 177 (David Held \& Anthony McGrew eds., 2003).

7. See About the Department of Defense, U.S. DEPARTMENT OF DEF., http://www.defense.gov/about/ (last visited July 31, 2010).

8. See Global Posture Review of United States Military Forces Stationed Overseas: Hearing Before S. Comm. on Armed Servs., 108th Cong. 6 (2004) (statement of Donald H. Rumsfeld, Secretary of Defense) [hereinafter Global Posture Review of U.S. Military Forces Stationed Overseas].

9. See id.

10. The Oxford English dictionary defines "rightsizing" as the process of "convert[ing] to an appropriate or optimum size." OXFORD ENGLISH DICTIONARY 1046 (3d ed. 2010).

11. See Ilan OSHRI ET AL., THE HANDBOOK OF GLOBAL OUTSOURCING AND OFFSHORING 4 (2009), for an applicable definitional outline of outsourcing and offshoring. 
This paper will show how the American security state has adapted to the new global security environment by adopting corporate strategies and will suggest the limitations that flow from its use of these strategies. Part I provides a brief history of U.S. overseas military bases, discusses the creation of the modern American security state, and examines the relationship between overseas military bases and the American security state. Part II describes the globalization of security, the transformation of the U.S. military, and how the DoD's twenty-first century overseas-basing structure is related to its twenty-first century military strategy. Part III argues that the DoD is operating like a transnational corporation to more effectively and efficiently "manufacture" security in its overseas military bases. Part IV describes how the DoD's current basing and diplomatic posture has negatively impacted diplomatic relationships and suggests how the DoD can improve and repair these relationships. Part V concludes with observations about the future of U.S. overseas military bases.

\section{A BRIEF History OF U.S. Overseas MILITARy Bases AND The AMERICAN SECURITY STATE}

Many of the bases currently in the DoD's possession were acquired during WWII ${ }^{12}$ when the number of U.S. overseas military bases increased to around 30,000 in 1945. ${ }^{13}$ After WWII, the United States began retracting its network of overseas base ${ }^{14}$ in response to pressure abroad to relinquish overseas bases to local governments and pressure at home to demobilize its massive military force. Within two years of Victory over Japan Day (V-J Day), "[h]alf of the wartime basing was gone ... and half of what had been maintained until 1947 had been dismantled by $1949 . " 15$

The modern American security state developed in the aftermath of WWII and "was defined by the parameters of the Cold War." 16 The DoD's Cold War strategy of "containment, confrontation, and intervention"17 was reflected in its overseas-basing posture: to counter a Soviet military threat and to impede the spread of Communism, bases

12. See U.S. Military Bases and Empire, 53 MONTHLY REv. 1, 2 (2002).

13. See id.

14. See id. at 3.

15. James R. Blaker, UNited States Overseas Basing: AN ANatomy of THE DILEMMA 32 (1990).

16. Robert G. Patman, Globalization, the End of the Cold War, and the Doctrine of National Security, in Globalization and Conflict: National SeCuRity in a "NeW" STRATEGIC ERA 3, 5 (Robert G. Patman ed., 2006).

17. Id. at 6. 
were established and large troop masses were deployed to western Europe and northeast Asia. ${ }^{18}$ The U.S. overseas-basing network further expanded as a result of the Korean War, reaching 1947 levels by $1967 . .^{19}$ Expansion continued until the end of the Vietnam War. ${ }^{20}$

The end of the Cold War "dramatically altered the security landscape that had shaped [the United States'] forward defense posture."21 In the post-Cold War security environment, weak or failing states, not superpowers, represented the greatest threats to national security, ${ }^{22}$ and identity politics and the "mobilization of movements along ethnic, racial, and religious lines" predominantly drove conflicts. ${ }^{23}$ In response to these threats, the United States acquired new bases throughout the 1990s to support its military interventions against weak or failing states in the Middle East and Eastern Europe. ${ }^{24}$

\section{The Globalization Of Security And The Transformation Of The MILITARY}

Globalization is a "multifaceted enterprise that proceeds both outside the state and within it, spurred on by businesses, consumers, social groups, states, and international institutions as they organize the economic, political, and cultural spheres beyond the nation-state." 25 Globalization has changed the nature of security and the traditional role of the state in providing it. ${ }^{26}$ Globalization has primarily affected the security state in two ways: 1) it has undermined state authority and 2) it has changed the nature of conflict. ${ }^{27}$ Both of these changes have made the security state (and hence, its citizenry) more vulnerable.

The security state's authority has diminished. Modern information technology and the mobility of capital have undermined the state's ability to control its economic destiny: "[w]here states were once the masters of markets, now it is the markets which . . . are the masters

18. See U.S. Dep'T of Def., Strengthening U.S. Global Defense Posture 5 (2004) (explaining the United States' defense posture throughout, and at the end of, the Cold War).

19. See Lutz, supra note 4 , at 14.

20. U.S. Military Bases and Empire, supra note 12, at 3.

21. U.S. DEP'T OF DEF., supra note 18, at 5.

22. See Patman, supra note 16, at 11.

23. Id.

24. U.S. Military Bases and Empire, supra note 12, at 5.

25. NORRIN M. RIPSMan \& T.V. PaUl, GLOBalization and the National SECURITy STATE 9 (2010).

26. See id. at 28.

27. See Kirshner, supra note 6, at 6. 
over ... states."28 Moreover, "authority in society and over economic transactions is legitimately exercised by agents other than states, and has come to be freely acknowledged by those who are subject to it."29 In this new global environment, the security state's ability to "manipulate domestic politics and ... to garner resources for war" 30 has been limited. Although the state still has a "monopoly on the ability to legitimize violence ... they do not have the ability to monopolize violence." 31

The nature of conflict has also changed. Interstate warfare, the purpose of the traditional security state, is increasingly rare, ${ }^{32}$ as wars are no longer fought on battlefields by massive armies. Globalization has also lowered the entry costs for state and nonstate actors to engineer and acquire new weapons technologies, such as weapons of mass destruction. ${ }^{33}$ Transnational terrorist groups are especially skilled at exploiting "globalization's assault on national borders to challenge nation-states." ${ }^{34}$ In the new global security environment, weak states "undermine the state from below, with smaller scale, open ended conflicts maintained by external support, criminal networks, and plunder."35

The nature of security has changed; in order to provide security for its citizens, the U.S. military has been transformed. In response to the new global security environment, the DoD created a new twenty-first century defense strategy. ${ }^{36}$ As part of the new defense strategy, defense planning shifted from a threat-based model to a capabilities-based model. ${ }^{37}$ Under the capabilities-based model, the DoD focused "on how an adversary might fight rather than specifically whom the adversary might be or where a war might occur." 38

28. Susan Strange, The Retreat of the State: The Diffusion of Power in the WORLD ECONOMY 4 (1996).

29. Susan Strange, The Declining Authority of States, in THE GLOBAL TRANSFORMATIONS READER: AN INTRODUCTION TO THE GLOBALIZATION DEBATE 127, 133 (David Held \& Anthony McGrew eds., 2003).

30. See Kirshner, supra note 6, at 6 .

31. See Clark, supra note 6, at 183 (emphasis omitted) (citing Daniel Deudney, Polticial Fission: State Structure, Civil Society, and Nuclear Security Politics in the United States, in On Security 87, 97 (Ronnie D. Lipschultz ed., 1995)).

32. See RiPSMAN, supra note 25, at 23.

33. See id. at 50.

34. Id.

35. Kirshner, supra note 6, at 9.

36. See generally U.S. DEP'T OF DEF., QUADRENNIAL DEFENSE REVIEW REPORT $2001 \mathrm{III}$, 3-10 (2001) [hereinafter QUADRENNIAL DEFENSE REVIEW REPORT].

37. See id. at IV, 13-14.

38. Id. at IV. 
The DoD's transformation efforts were "built on several conceptual pillars, foremost among them agility, flexibility, and speed." 39 The transformed United States military would be a "more agile, more efficient force," one "that is ready and able to combat the asymmetric challenges of this new and uncertain time." 40 A key step in transforming the military was to identify new ways to deter conflict.41 However, conflict deterrence would still primarily depend upon the power of military presence: "[d]eterrence in the future will continue to depend heavily upon ... forward stationed and forward deployed combat and expeditionary forces . . . along with the rapidly employable capabilities that the U.S. military possess throughout the globe." 42

Military presence ultimately depends on military bases; however, in the new global security environment, the United States cannot anticipate where wars might occur. Consequently, the DoD's new defense posture "emphasiz[es] long-term military access to countries over long-term military presence within countries"43 and therefore allows for strategic flexibility.

\section{The DePartment Of Defense: A Transnational CoRPoration}

The DoD is the largest government agency in the United States and one of the largest organizations in the world. The DoD:

manages twice the budget of the world's largest corporation, employs more people than the population of a third of the world's countries, provides medical care for as many patients as the largest health management organization, and carries five hundred times the number of inventory items as the world's largest commercial retail operation. ${ }^{44}$

39. See Gerson, supra note 2, at 63.

40. Global Posture Review of U.S. Military Forces Stationed Overseas, supra note 8, at 6.

41. See QUADRENNIAL DEFENSE REVIEW REPORT, supra note 36, at 25.

42. $I d$.

43. Todd W. Fields, Eastward Bound: The Strategy and Politics of Repositioning U.S. Military Bases in Europe, 15 J. PUB. \& INT'L AFF. 79, 82 (2004).

44. JACQUES S. GANSLER \& WILLIAM LUCYSHYN, DEFENSE BUSINESS TRANSFORMATION 17 (2009). 
It operates out of the Pentagon, one of the world's largest office buildings. ${ }^{45}$ And, since the early 2000s, it has operated like a transnational corporation.

The DoD is in the security industry: it "manufactures" the product known as security. It faces new competitors (China) and new obstacles (a weakened U.S. economy). ${ }^{46}$ China's "soft" power continues to increase: "[a]ll over the globe ... the Chinese are becoming masters of indirect influence - by establishing business communities and diplomatic outposts, by negotiating construction and trade agreements. Pulsing with consumer and martial energy ... China constitutes the principal conventional threat to America's liberal imperium."47 National security and the national economy are linked: if one is weak, so is the other. ${ }^{48}$ To continue to compete in the security market, the DoD must modernize and streamline its military infrastructure; it must transform the U.S. military. The DoD is restructuring its overseas-basing posture to accomplish this.

The $\mathrm{DoD}$ is rightsizing bases, outsourcing base labor, and offshoring bases primarily to achieve its strategic goals; for the DoD, these techniques are an end unto themselves. Security is the "dividend" the DoD pays to its "shareholders," U.S. citizens. These corporate strategies are also economical and distribute savings on the manufacturing of security to the shareholders. Rightsizing and outsourcing reduces costs, while offshoring avoids them. Transnational corporations, on the other hand, rightsize, outsource, and offshore to reduce costs and increase profits for shareholders; for transnational corporations, these techniques are a means to an end. The DoD's transformation efforts, which emphasizes flexibility, agility, and efficiency, echoes the operational objectives of many transnational corporations. Consequently, the DoD is operating like a transnational corporation by using these corporate techniques to manage its overseas bases.

45. See About the Department of Defense, supra note 7 (last visited Dec. 2, 2010).

46. See generally, e.g., Obama Says U.S. Economic Fix Could Take Years, REUTERS, Dec. 9, 2009, available at http://www.reuters.com/article/2011/12/10/usa-economy-obamaidUSN1E7B80WK20111210. 49.

47. Robert D. Kaplan, How We Would Fight China, ATLANTIC MAG., June 2005, at 49,

48. NATIONAL SECURITY STRATEGY, supra note 3, at 10 ("Rebuilding our economy must include putting ourselves on a fiscally sustainable path. As such, implementing our national security strategy will require a disciplined approach to setting priorities and making tradeoffs among competing programs and activities. Taken together, these efforts will position our nation for success in the global marketplace, while also supporting our national security capacity - the strength of our military, intelligence, diplomacy and development, and the security and resilience of our homeland."). 


\section{A. Rightsizing}

Like a transnational corporation rightsizing (i.e., reducing its workforce to the optimum size) in response to a new economic environment, the DoD is rightsizing in response to a new security environment: it is creating new types of bases, it is closing bases that are no longer effectively "manufacturing" security, and it is restructuring those that remain open. The 2004 Global Posture Review and the conclusions of the 2005 Base Realignment and Closing Commission (BRAC) illustrate the DoD's rightsizing efforts, which are integral to executing its new defense strategy.

\section{The 2004 Global Posture Review}

The changes enacted by the 2004 Global Posture Review represent the "biggest restructuring of America's global forces since 1945." 49 The Global Posture Review is "intended to reduce United States overseas forces over a six-to-eight-year period from the numbers and locations of overseas bases . . . left over from the Cold War to new locations optimized to support current allies and confront new potential threats." More specifically, the Global Posture Review would return 70,000 troops to the United States, close 300 overseas military bases, and save $\$ 1$ billion per year. ${ }^{50}$

Restructuring America's global forces requires diversifying U.S. military bases. ${ }^{51}$ Consequently, the DoD has developed "plans for a more flexible and effective force posture for the twenty-first century." 52 This new posture calls for the DoD to operate and maintain three types of military bases: Main Operating Bases (MOBs), Forward Operating Sites (FOSs), and Collaborative Security Locations (CSLs).

MOBs have "permanently stationed combat forces, extensive infrastructure . . . command and control headquarters, and accommodations for families." 53 The Ramstein Air Base in Germany and the Kadena Air Base in Japan are examples of MOBs. ${ }^{54}$

49. Chalmers Johnson, Nemesis: The last Days Of The American Republic 144 (2006) [hereinafter JOHNSON, NEMESIS] (quoting Secretary of Defense Donald H. Rumsfeld).

50. See Robert D. Critchlow, Cong. Research Serv., Rl33148, U.S. Military OVERSEAS BASING: NEW DEVELOPMENTS AND OVERSIGHT ISSUES FOR CONGRESS 2 (2005).

51. See generally Gerson, supra note 2, at 60 (discussing a variety of ways America's overseas military bases might be changed and diversified). 5.

52. Global Posture Review of U.S. Military Forces Stationed Overseas, supra note 8, at

53. JOHNSON, NEMESIS, supra note 49 , at 145 .

54. Id. 
The DoD would also establish a network of FOSs. FOSs are "expandable host-nation 'warm site[s]' with a limited U.S. military support presence and possibly prepositioned equipment." 55 Troops would "deploy to these bases for temporary duty (typically one year or less, unaccompanied by families)." 56 In essence, they are just smaller MOBs. ${ }^{57}$

Finally, the DoD would create CSLs. A CSL can be "a tucked-away corner of a host country's civilian airport, or a dirt runway somewhere with fuel and mechanical help nearby, or a military airport."58 These bases, which are also known as "lily pads," 59 are inexpensive, flexible, and scalable. ${ }^{60}$ Lily pads provide a stable location to which "our troops [can] jump like so many well-armed frogs from the homeland or our major bases elsewhere." 61 These bases have little or no permanent U.S. troop presence, are maintained by host nation personnel or private contractors, ${ }^{62}$ and house prepositioned ammunition and weapons that U.S. troops can access only in times of emergency. ${ }^{63}$

CSLs also serve diplomatic purposes. As part of the process of establishing a CSL, the U.S. military will upgrade the host nation's military installations, facilitate joint-training exercises with the host nation's military, and engage in humanitarian work in the area. In essence, the military's actions in nations hosting CSLs are directed towards cultivating the nation's goodwill, so that the United States can get "the host country's approval for use of the base when and if [it] need[s] it." 64

\section{The 2005 Base Realignment and Closure Commission}

In 1988, Congress created the BRAC, "an independent group of . . . commissioners, consisting of former legislators, members of the business community, retired military personnel, and former presidential

55. Global Posture Review of U.S. Military Forces Stationed Overseas, supra note 8, at 7 (statement of General James L. Jones, Jr., USMC).

56. CRITCHLOW, supra note 50, at 2.

57. See JOHNSON, NEMESIS, supra note 49 , at 146 (discussing the differences between Forward Operating Sites and Main Operating Bases).

58. Kaplan, supra note 47 , at 49.

59. JOHNSON, NEMESIS, supra note 49 , at 147.

60. Global Posture Review of U.S. Military Forces Stationed Overseas, supra note 8, at 6 (statement of Donald H. Rumsfeld, Sec'y of Defense) (discussing some of the advantages of Forward Operating Sites).

61. See JOHNSON, NEMESIS, supra note 49, at 147.

62. See id.

63. See id.

64. Kaplan, supra note 47 , at 49. 
appointees."65 The Defense Base Closure and Realignment Act of 1990 governs the BRAC process. ${ }^{66}$ The BRAC was created to serve as an impartial administrative body responsible for reviewing and analyzing the DoD's recommended list of bases and military installations to be closed or realigned. ${ }^{67}$ As part of its review, the BRAC is required to assess whether the DoD's recommendations meet certain statutory selection criteria. During the review process, the BRAC can add installations to the DoD's list.

There have been BRAC closing or realignment rounds in 1988, 1991, 1993,1995 , and 2005. ${ }^{68}$ The 2005 BRAC, which has been the largest yet, affected twenty to twenty-five percent of the DoD's military installations. The primary purpose behind the 2005 BRAC was military transformation": it allowed the DoD to "rationaliz[e] [U.S. military] infrastructure with [the DoD's] defense strategy."70 Per the 2005 BRAC, the DoD will close or realign 182 military bases by September 2011.71 These base closures and realignments are estimated to result in an annual savings of $\$ 4.2$ billion. ${ }^{72}$

\section{B. Outsourcing}

The DoD, "like the best companies . . . in the United States," 73 is constantly looking for ways to "manufacture" security as cheaply and efficiently as possible. The DoD, like many transnational corporations, ${ }^{74}$ found the solution in outsourcing. Outsourcing is the process through which organizations contract with third-party service providers "for the management and completion of a certain amount of work, for a specified

65. LiLy J. GORen, The POLITICS OF Military Base Closings: Not IN My District 1 (2003).

66. See Office of the Secretary of Defense: Base Realignment and Closure Frequently Asked Questions, U.S. DEPARTMENT OF DEF., http://www.defense.gov/brac/02faqs.htm (last visited Dec. 13, 2010).

67. See About the Commission, DEF. BASE Closure AND REALIGNMENT Commission, http://www.brac.gov/About.html (last visited Dec. 18, 2010).

68. See David M. BEarden, Cong. ReSEarch SerV., RS22065, Milutary Base Closures: Cleanup Of CoNTAMINATED PROPERTIES For CIVILIAN REUSE 1 (2008).

69. See BASE Closure AND REAlignMENT COMm'N, EXECUTIVE SUMmary 2005, pt 1, at iii (2005) [hereinafter BRAC EXECUTIVE SUMMARY].

70. George Cahlink, Pentagon Sees Base Closing as Critical To Larger Strategy, NAT'L J., Jan. 30, 2004, available at http://www.govexec.com/dailyfed/0104/013004g1.htm (quoting Deputy Undersecretary of Defense (Installations and Environment) Philip Grone).

71. See BRAC EXECUTIVE SUMMARY, supra note 69 , at iii.

72. See id.

73. 11 DeP'T OF DEF., IMPRoving THE Combat EDge Through OUTSOURCING 1(1996).

74. See OSHRI, supra note 11 , at 4. 
length of time, cost, and level of service."75 Outsourcing generates savings, provides flexibility, reduces training costs, ${ }^{76}$ and thus allows an organization to "obtain higher levels of performance at a lower cost with relatively little upheaval for the organisation."77

Outsourcing has become an integral part of modern DoD operations. After September 11, 2001, the DoD turned to private defense companies to supplement its in-house defense force. ${ }^{78}$ Between 2000 and 2005 , the DoD's contracting budget grew by 102.3 percent. ${ }^{79}$ The DoD has hired contractors to perform "core military tasks and . . . orchestrate operations." 80 It has contracted with private corporations for weapons and technology development and management. ${ }^{81}$ In the war in Afghanistan, private contractors "served in paramilitary units . . . maintained combat equipment, provided logistical support, and worked on surveillance and targeting." 82

The DoD has used private contractors to operate, secure, build, and maintain overseas bases. In Iraq, the DOD employed over 39,000 private contractors to perform "base support functions such as maintaining the grounds, running dining facilities, and performing laundry services." 83 Private contractors have provided base security ${ }^{84}$ and constructed military bases in Iraq. ${ }^{85}$ Most notably, Kellogg, Brown, and Root (KBR), an engineering and construction firm, has been highly involved in the construction of these bases. The DoD has paid KBR at least $\$ 4.5$ billion to construct and maintain U.S. bases in Iraq and Afghanistan. KBR has built some of the largest military installations in Iraq, including Camp Victory North. Camp Victory North is a "small American city," capable of housing 14,000 troops. 86 KBR has been

75. Id.

76. Martha Minow, Outsourcing Power: Privatizing Military Efforts and the Risks to Accountability, Professionalism, and Democracy, in GovernMENT BY CONTRACT: OUTSOURCING AND AMERICAN DEMOCRACY 110, 113-14 (Jody Freeman \& Martha Minow eds., 2009) (discussing the advantages and disadvantages of privatizing the delivery of government services).

77. Ronan MCIvor, The OUTSOURCING Process: Strategies for Evaluation AND MANAGEMENT 1 (2005).

78. See Minow, supra note 76, at 112.

79. Id. at 110 .

80. Id. at 112 .

81. See id.

82. Id.

83. Moshe Schwartz \& Joyprada Swain, Cong. Research SERV., R40764, DEPARTMENT OF DEFENSE CONTRACTORS IN AFGHANISTAN AND IRAQ: BACKGROUND AND ANALYSIS 15 (2011).

84. See Minow, supra note 76, at 112.

85. See JOHNSON, NEMESIS, supra note 49, at 159.

86. Id at 161. 
involved in the construction of Camp al-Rasheed, Camp Cook, Balad Airbase, Camp Anaconda, and Camp Marez. ${ }^{87}$

The DoD has also been outsourcing the maintenance of CSLs. Retired U.S. noncommissioned officers ${ }^{88}$ who are maintenance experts, speak the native language fluently, and are generally well-liked by members of the local community frequently operate CSLs. The contractor rents military facilities from the host nation's military, and charges a fee for the U.S. military's use of the facilities. ${ }^{89}$

The use of private contractors as gatekeepers to CSLs and to host nations allows the DoD to sidestep steep monetary and political transaction costs. Private contractors charge low fees in comparison to the costs associated with feeding, outfitting, monitoring, and paying DoD employees. Furthermore, citizens of host nations are often suspicious of U.S. troops at best, and resentful of them, at worst. Many host nations have a complex relationship with the DoD. Private contractors allow the host nations to indirectly work with the DoD.90 This allows local politicians to condemn the U.S. military presence while simultaneously reaping the benefits from it. Finally, private contractors prevent "incidents," such as the rape of local women, from happening by steering U.S. troops to the "right hotels and bars, and advising them on how to behave." 91 Criminal acts by U.S. troops stationed overseas have had a deleterious effect on United States-host nation relations. ${ }^{92}$ In some instances, such acts have resulted in "some of the largest antiAmerican demonstrations in postwar history." 93

\section{Offshoring}

The closure of a domestic base is politically charged and contentious, and military bases contaminate the soil on which they are built. ${ }^{94}$ After a base is closed, environmental cleanup is expensive and often

\footnotetext{
87. See id. at 161-62.

88. See KAPLAN, supra note 47 , at 49.

89. See id.

90. See id (explaining how operating through a private contractor allows a host nation to avoid the appearance of working with the U.S. military or government).

91. Id.

92. See JOHNSON, NEMESIS, supra note 49 , at 179-80.

93. Id. at 179.

94. See, e.g., Katherine T. McCaffrey, Environmental Struggle After the Cold War: New Forms of Resistance to the U.S. Military in Vieques, Puerto Rico, in THE BASES OF EMPIRE: The Global Struggle Against U.S. Military Posts 218, 237 (Catherine Lutz ed., 2009)(describing the United States military's environmental damage to Vieques, Puerto
} Rico). 
ineffective. ${ }^{95}$ The closure of an overseas military base, on the other hand, is not politically contentious in the same way domestic base closures are and the U.S. military, through clever legal maneuvers, has made itself judgment-proof for any pollution associated with its overseas military bases. Thus, by having bases offshore, the DoD can reduce political and environmental transaction costs.

Overseas bases, by definition, are already offshore. They exist to provide force projection and to protect American interests; cost avoidance is an attendant boon. On the other hand, transnational corporations have offshore operations to decrease costs and increase efficiencies. Although the DoD and transnational corporations have different reasons for offshoring, both enjoy the same benefits. Thus, in this mediated sense, the DoD is using offshoring to manage overseas military bases. By avoiding these costs, the DoD can manufacture security more economically.

\section{The Transaction Costs of Domestic Base Closings}

Domestic base closures are the "political equivalents of earthquakes, volcanic eruptions, or category five hurricanes." ${ }^{6}$ News of a domestic base closure elicits "panic-stricken lamentations among politicians of both parties ... and the business and labor communities of the places where military facilities are to be shut down. All of them plead 'save our base." 97 States fight to keep their bases open. California Governor Arnold Schwarzenegger used his 2004 State of the State Address to comment on the specter of military base closures in California:

The Pentagon will make the next round of base closures in 2005 ... . This could mean thousands of lost jobs to California. These bases are important to national defense, and they are important to our steady economic recovery. As a state, we will fight to keep our bases open. .9

California is not the only state that has vowed to keep its bases open. Florida, Texas, and Arizona have taken action by "hiring lobbyists,

95. See id. at 237 (discussing the difficulties and costs involved in cleaning up depleted uranium).

96. See Johnson, Nemesis, supra note 49, at 138 (citing George Cahlink, Pentagon Certifies Need for Base Closures, Gov'T EXECUTIVE MAG., Mar. 23, 2004).

97. Id. at 137-38.

98. See CAHLINK, supra note 70 , at 34 . 
launching 'save-our-base' campaigns, and investing millions of dollars in nearby infrastructure improvements." 99

Under the Comprehensive Environmental Response, Compensation, and Liability Act (CERCLA), the federal government is required to clean up a domestic military base before it is transferred to nonfederal entities. The DoD typically undertakes this duty for military bases. ${ }^{100}$ After the property is transferred, the United States remains liable for any remaining contamination. ${ }^{101}$ CERCLA requires the DoD to clean up the site until the level of contamination does not pose risks to human health or the environment. ${ }^{102}$ The extent of cleanup required depends on the planned uses for the site; residential uses have more stringent requirements than industrial uses.

Cleanup may be delayed or prolonged over many years. ${ }^{103}$ Commercial redevelopment is dependent on site cleanup, and the recovery of the local economy is often dependent on redevelopment. Consequently, recovery is usually impossible until cleanup is complete; however, CERCLA does authorize transfer before the cleanup under certain conditions. ${ }^{104}$ Transferring before cleanup can facilitate the redevelopment process when cleanup and development can be done concurrently. 105

Base cleanup is expensive. ${ }^{106}$ There have been five BRAC closing rounds, and the total cost of base cleanup for those rounds is over $\$ 11$ billion. 107

\section{Avoiding Costs Overseas}

By building and operating overseas bases, the United States can avoid the political transaction costs associated with domestic base closures as the closure of an overseas base does not negatively affect the

99. Id.

100. See David M. Bearden, Cong. Research Serv., RS22065, Military Base Closures: Cleanup Of Contaminated Properties For Civilian Reuse 2 (2008) (discussing the implications of the 1986 amendment to the Comprehensive Environmental Response, Compensation, and Liability Act (CERCLA) and the requirements imposed by this act on the United States with regard to contaminated federal property).

101. See id.

102. See id. at 3.

103. See id. at 6 (the level of contamination of a site, the capabilities of cleanup technologies, and funding are factors that may affect how quickly a cleanup might occur).

104. See id. at 2.

105. See id.

106. See Katherine T. McCaffrey, Environmental Struggle After the Cold War: New Forms of Resistance to the U.S. Military in Vieques, Puerto Rico, in THE BASES OF EMPIRE: The Global STRuggle Against U.S. MilitaRY Posts 218, 237 (Catherine Lutz ed., 2009). 107. Id. at 6 . 
American economy. However, overseas military bases disconcert some Americans: they are concerned with the cost of keeping them open and are clamoring for many of them to be closed. 108

The United States also is able to usually avoid costs by contracting out of liability for any pollution associated with its overseas military bases. Prior to building or using an overseas military base, the United States negotiates a contract with the host nation. ${ }^{109}$ This contract, which creates an "alliance" between the United States and the host nation, is a "short, straightforward treat[y] that express[es] "common objectives' related to 'national security' and 'international threats to the peace."'110

Once the United States has formed an "alliance" with the host nation, it negotiates a Status of Forces Agreement (SOFA). The SOFA "establishes the framework under which armed forces operate within a foreign country"111; it ensures that U.S. personnel present in a host nation have rights and legal protections. ${ }^{112}$ Although the United States shares jurisdiction with some countries, it primarily uses the SOFA to retain exclusive jurisdiction, and to "put any U.S. forces stationed in the host country as far beyond its domestic laws as possible."113 SOFAs undermine the host nation's sovereignty, ${ }^{114}$ and thus inevitably "give rise to explosive political disputes." 115 Host nations must also engage in "burden sharing" with the United States.116 Under "burden sharing," host nations pay the United States to support its presence in their country. ${ }^{117}$ In 2002, Japan, which spends the largest amount of any country, paid $\$ 4.4$ billion.

Many host nations, including major players such as Germany and Japan, are becoming increasingly frustrated with the U.S. military's "above the law" attitude. Under Germany's SOFA with the United States, the United States is responsible for environmental and noise pollution. ${ }^{118}$

108. See generally, e.g., David Vine, Too Many Overseas Bases, ForeIGN PoL'Y Focus (Feb. 25, 2009), http://www.fpif.org/articles/too_many_overseas_bases.

109. See JOHNSON, EMPIRE, supra note 1, at 117.

110. JOHNSON, NEMESIS, supra note 49, at 171.

111. See R. Chuck Mason, Cong. Research SerV., RL34531, Status Of Forces AgREEMENT (SOFA): What Is It, AND How HAS It BeEN UTILIZEd? 5 (2011).

112. Id.

113. See JOHNSON, NEMESIS, supra note 49 , at 171.

114. See id. at 176 (describing the sovereign rights of host nations that are often infringed upon by SOFAs).

115. $I d$.

116. See id. at 150.

117. See id.

118. See id. at 174 (explaining that "the [SOFA] agreements [between] individual European countries [and the U.S.] do not contain exemptions from responsibility for environmental and noise pollution"). 
Nevertheless, the U.S. military has polluted the land around its bases in Germany and has refused to clean it up. Germany's ire with the U.S. military has kicked off a race to the bottom among the poorer countries in Eastern Europe, such as Bulgaria, Poland, and Romania, which have less stringent environmental regulations. ${ }^{119}$ These countries are "poor and desperate enough to be willing ... to let the Americans pollute as they wish, cost free, in order to get what economic benefits they can."120

The United States has polluted in Japan. The U.S. military has used the reservoir of the Fukuchi Dam, which provides water to the residents of Okinawa, for training exercises, and "significant amounts of discarded munitions have been discovered in the surrounding watershed area."121 However, Japan is powerless to prevent this pollution or to compel the United States to remediate the environmental damage it causes. In their SOFA with Japan, the United States explicitly contracted away liability for any environmental damage its military bases might cause. 122

According to Article 18 (5)(3) of the SOFA, Japanese citizens have the power to sue and collect damages from the United States. ${ }^{123}$ However, despite this provision in the SOFA, Japanese citizens are also powerless to hold the United States liable for its environmental degradations. Although many successful suits have been brought (including one assessing more than $\$ 24$ million in damages), the United States will not pay. ${ }^{124}$ From the United States' perspective, "it is 'strange' that the American military should have to pay damages for practicing warfare to protect Japan." 125

\section{THE DARK SIDE OF EFFICIENCY: THE END OF COOPERATION}

The DoD's twenty-first century global posture, which "emphasiz[e]s long-term military access to countries," relies heavily on the cooperation

119. See id. at 149 .

120. Id. at 174 .

121. Id. at 173 .

122. Article 6 of the SOFA, the section containing the "no liability" provision, reads: "The United States is not obliged, when it returns facilities and areas . . . to restore the facilities and areas to the condition in which they were at the time they became available . .. or to compensate Japan ... in lieu of such restoration." Id. at 172.

123. Article $18(5)(3)$ of the SOFA reads: "Where the United States alone is responsible [in a civil claims case], the amount awarded or adjudged shall be distributed in the proportion of 25 percent chargeable to Japan and 75 percent chargeable to the United States." Id. at 173.

124. See id.

125. Id. 
and goodwill of host nations. ${ }^{126}$ However, the DoD's overseas military bases create many negative externalities, which host nations are ultimately forced to absorb. Consequently, countries worldwide have become increasingly hostile toward U.S. overseas military bases. ${ }^{127}$ In order for the DoD to continue to economically manufacture security using the corporate strategies of rightsizing, outsourcing, and offshoring, a balance must be struck between efficiency and diplomacy.

This section consists of two subsections. The first subsection describes how the DoD's current basing and diplomatic posture has negatively impacted diplomatic relationships with host nations and how U.S. responses to these negative externalities have caused diplomatic relations to further deteriorate. The second subsection suggests how the DoD can improve and sustain diplomatic relations by striking the proper balance between efficiency and diplomatic decency.

\section{A. Negative Externalities}

Overseas military bases create negative social externalities in host nations. Perhaps the most representative example of these negative social externalities is the history of military violence against the women of Okinawa, Japan. ${ }^{128}$ Since the U.S. occupation at the end of WWII, Okinawan women have been the victims of military violence. Between WWII and the Korean War, sexual and physical violence against Japanese women was "rampant and indiscriminate." 129 In recent years, date-rape violence has been increasing. ${ }^{30}$ The most notorious and reprehensible incident of rape occurred in September 1995 when two Marines and a sailor "abducted a twelve-year-old girl they picked out at random, beat and raped her, and left her on a beach."131 After the rape, the United States invoked Article 17 of their Japanese SOFA-which gives the United States jurisdiction over crimes committed by U.S. troops in Okinawa-and refused to surrender the soldiers to Japanese authorities. ${ }^{132}$ The rape and the U.S. military's response to it shocked the people of Okinawa, incited massive anti-American

126. See FIELDS, supra note 43, at 82.

127. See Lutz, supra note 4 , at 31 (listing examples of countries and events which demonstrate hostility to a U.S. military presence).

128. See Kozue Akibayashi \& Suzuyo Takazato, Okinawa: Women's Struggle For Demilitarization, in The Bases of EMPIRE: The GLobal Struggle Against U.S. MILITARY POSTS 243, 261 (Catherine Lutz ed., 2009) (describing the prevalent and overt forms of violence committed against Okinawan women by American service members).

129. Id.

130. Id. at 262 .

131. Johnson, NEMESIS, supra note 49 , at 179.

132. See id. 
demonstrations, ${ }^{133}$ and spearheaded a movement to expel U.S. troops from the island. ${ }^{134}$ In 2005, after ten years of unrest and continuing military violence against Okinawan women, the United States agreed to transfer, over a six-year period, thousands of U.S. troops from Okinawa to Guam.

Overseas military bases also create negative environmental externalities. Perhaps the most representative example of these negative environmental externalities is the history of U.S. military pollution in Vieques, Puerto Rico. For sixty years, the island of Vieques was the home of a U.S. Navy live-bombing range and an ammunition facility, ${ }^{135}$ and over those sixty years, the U.S. Navy's pollution greatly damaged the local ecosystem. ${ }^{136}$ On the western side of the island, the U.S. Navy disposed of nearly "[two] million pounds of military and industrial waste."137 In 2005, the Environmental Protection Agency listed the Navy's live-bombing range, which was located on the eastern side of Vieques, as one of the most hazardous waste sites in the United States. ${ }^{138}$ The land and water surrounding the range have been extensively polluted: "[c]oral reefs and sea-grass beds have sustained significant damage from bombing, sedimentation, and chemical contamination. The groundwater has been contaminated by nitrates and explosives." 139 Furthermore, the range has been "seriously contaminated by heavy metals" such as depleted uranium, and "studies have documented that those metals have entered the food chain." 140 In May 2003 , after years of protests and demonstrations, the U.S. Navy was expelled from Vieques. ${ }^{141}$

The United States has not responded diplomatically to complaints about the negative externalities caused by its overseas-basing.

In response to the rape of the twelve-year-old Okinawan girl, General Richard Meyers, commander of U.S. forces in Japan, said "this was a singular tragedy caused by 'three bad apples' even though he knew that sexually violent crimes committed by U.S. soldiers against Okinawans were running at the rate of two per month."142 And, Admiral Richard Macke, commander of U.S. forces in the Pacific, said: "I think

133. See id.

134. See Akibayashi \& Takazato, supra note 128 , at 260.

135. See McCaffrey, supra note 106, at 234.

136. See id (explaining that constant bombing "devastated" the area and left "spent shells and live bombs ... bomb craters and toxic-waste").

137. Id. at 235 .

138. Id. at 236.

139. Id.

140. Id.

141. Id. at 233.

142. See JOHNSON, NEMESIS, supra note 49 , at 180. 
that [the rape] was absolutely stupid. For the price they paid to rent the car [with which to abduct their victim], they could have had a girl."143 These impolitic comments only served to fuel the fire of outrage in Okinawa.

High-ranking officers responded to the claims of the Vieques movement by arguing, in effect, that the United States military is the victim, not the people of Vieques. According to the U.S. military, civilian encroachment on the military installations on Vieques undermined the military's ability to use these installations for training. ${ }^{144}$

\section{B. The Balance between Efficiency and Diplomacy: Respect Allies and Follow the Law}

It will be difficult for the DoD to find the balance between efficiency and diplomacy. On one hand, the DoD's new overseas-basing strategy and its use of rightsizing, outsourcing, and offshoring to manage its overseas military bases have reduced overhead and allowed the DoD to manufacture security more economically. On the other hand, the DoD's overseas-basing strategy and the negative externalities caused by overseas bases have resulted in the United States military being expelled from many countries.

It is tempting for the DoD to continue to cut diplomatic corners; however, cutting corners has cost the DoD the cooperation of allies, and in order for the DoD to continue manufacturing security, it will need the cooperation of foreign countries more than ever. If the DoD does not redress the wrongs created by overseas military bases and work to prevent similar wrongs from occurring in the future, it will not be able to fully actualize and maintain its overseas-basing posture, and will therefore not be able to provide security to American citizens. Because the DoD is closing many overseas bases and creating smaller bases with no permanent troop presence, many of the issues associated with overseas military bases, such as pollution and rape, might become moot. Nevertheless, the DoD will still maintain major bases in foreign countries, and if the DoD does not find the balance between efficiency and diplomacy, the continued presence of these bases will be jeopardized. Consequently, to achieve the necessary balance between efficiency and diplomacy, the United States must: 1) discontinue the use of SOFAs, or at the very least, engage in fair bargaining practices and forge bilateral SOFAs with all host nations; 2) consistently and transparently prosecute U.S. troops for crimes committed in host

143. Id.

144. See McCaffrey, supra note 106 , at 230. 
nations; and 3) clean up overseas military bases and prevent pollution from occurring in the future.

SOFAs allow the DoD to impose its will on host nations, to undermine the host nation's sovereignty, and to cause diplomatic strife. Thus, SOFAs inherently undermine the alliance between the United States and the host nation. In an ideal world, the United States would discontinue the use of SOFAs. However, this may not be possible or practical. Consequently, the United States must, at the very least, engage in a meaningful SOFA-bargaining process with host nations: it must form a true alliance with the host nation, an alliance based on mutual trust and assurances. As part of this bargaining process, burden sharing can be used as a bargaining chip. For example, a host nation may allow the United States to opt out of some liability for pollution if the United States pledges to minimize pollution and does not require the host nation to engage in burden sharing. Moreover, to ensure goodwill and continued cooperation, the DoD should forge bilateral SOFAs with all host nations, not just with countries that have the power to bargain for them. The United States must carefully guard its reputation abroad-if prospective host nations know that the United States has a history of polluting, it will be more difficult to enlist them as our allies.

If the United States is going to continue to demand immunity for its American troops overseas, at the very least, it must consistently prosecute troops who commit crimes in a host nation. U.S. troops must be held accountable for any criminal acts they commit in host nations, and the United States High Command should establish a top-down policy of instructing troops that they will be prosecuted for crimes they commit. By putting U.S. soldiers on notice, the United States will increase the likelihood that they will not commit crimes. Collaborating with the host nation's law enforcement, and transparently prosecuting U.S. troops will ensure that the host nation's citizens will feel that justice has been served. Because the DoD's new defense strategy is so dependent upon the cooperation of host nations, the United States must actively foster goodwill and trust. If the United States does not win the hearts and minds of the local populace, it will continue to risk being expulsed from host nations, as it was in Japan.

Although cleaning up overseas military bases will be expensive, not doing so will jeopardize relations with host nations. If the DoD pollutes, it must cleanup after itself. Prevention is often cheaper than remediation, so the DoD should establish procedures for the proper disposal of military and industrial waste. The DoD could design these procedures based on U.S. environmental law or the laws of the host nations. As a sign of good will, the DoD should follow the more stringent 
of either its laws or the laws of the host nation. Countries will be more willing to allow the United States to build bases on their soil if the United States has a record of not polluting or, at the very least, a record of cleaning up after itself. ${ }^{145}$

\section{ConClusion: The FUTURE OF U.S. OVERSEAS MILITARY BaSES}

The DoD is at a crossroads: it can continue on its current trajectory and risk the end of cooperation, or it can make deviations, right its wrongs, and ensure cooperation. Unlike a transnational corporation, the DoD cannot literally become bankrupt; however, if it is not managed properly, it no longer will manufacture security and, effectively, become bankrupt.

Unless the U.S. economy improves, the DoD will face increasing pressure to shut down overseas bases for economic, not strategic reasons. In fact, there is already mounting pressure to do so. ${ }^{146}$ The DoD's large discretionary budget is constantly under scrutiny. The huge costs and, for many U.S. Citizens, tangential benefits associated with oversea bases will only magnify this scrutiny. Consequently, in upcoming elections, overseas military bases will become a hot button issue.

By 2014, the DoD will transfer 8,000 Marines and 9,000 dependents from Okinawa to the U.S. territory of Guam. ${ }^{147}$ In addition, new military installations, costing $\$ 10.3$ billion, sixty percent of which will be paid by Japan, will be built on Guam. ${ }^{148}$ The way that the DoD bases troops in Guam will provide insight into the way the DoD will operate in the coming years. It may also presage the DoD's future ability to manufacture security in its overseas military bases.

145. Reducing pollution also benefits the United States outside of the context of SOFAs. Polluting overseas, especially ocean pollution, will eventually have a negative impact on the United States.

146. See, e.g., Nicholas D. Kristof, The Big (Military) Taboo, N.Y. TIMES, Dec. 26, 2010, at WK16 (arguing, inter alia, that the United States needs less military and more diplomacy); John Pomfret, What's The Big Idea? Closing Military Bases, WASH. PosT, Apr. 5, 2009, at D1.

147. See ShIRley A. Kan \& LaRRY A. NikSCH, Cong. Research SERV., RS22570, GuAM: U.S. DEFENSE DEPLOYMENTS 3 (2009).

148. See id at 7 . 
